\title{
AKURASI MOVING A VERAGE DALAM PREDIKSI SAHAM LQ45 DI BURSA EFEK INDONESIA
}

\author{
Ni Nyoman Mira Cahyani ${ }^{1}$ \\ Luh Putu Mahyuni \\ 1,2 Program Studi Magister Manajemen Universitas Pendidikan Nasional, \\ Bali, Indonesia \\ 1email: imoetmira05@gmail.com \\ 2email: mahyuniluhputu@undiknas.ac.id
}

\begin{abstract}
ABSTRAK
Penelitian ini bertujuan untuk menguji dan memberikan bukti empiris akurasi salah satu indikator analisis teknikal, yaitu moving average dalam memprediksi arah pergerakan harga saham LQ45 di Bursa Efek Indonesia (BEI). Untuk mencapai tujuan penelitian, sampel 37 saham perusahaan dikumpulkan dengan teknik purposive sampling. Saham yang digunakan sebagai sampel adalah saham yang mengalami kejadian Golden Cross dan Death Cross selama periode pengamatan, yaitu Pebruari-Juli 2019. Data diperoleh melalui aplikasi Esmart. Untuk menguji hipotesis penelitian terkait keakuratan metode moving average, dilakukan uji nonparametrik Mann-Whitney yang dapat membuktikan secara statistik apakah terdapat perbedaan signifikan antara prediksi arah pergerakan harga saham yang dihasilkan metode moving average dengan kenyataannya. Hasil penelitian ini menemukan tidak ada perbedaan antara prediksi arah pergerakan harga saham yang dihasilkan metode moving average dengan kenyataannya. Dengan demikian, penelitian ini memberikan bukti empiris keakuratan metode moving average dalam memprediksi arah pergerakan harga saham yang tergabung dalam indeks LQ45, dengan periode pengamatan yang singkat. Temuan penelitian ini dapat menjadi referensi bagi investor pasar modal dalam memilih metode analisis teknikal yang dapat membantu pengambilan keputusan investasi yang lebih tepat.
\end{abstract}

Kata Kunci: Analisis Teknikal; Akurasi Moving Average; Saham; Keputusan Investasi

\begin{abstract}
This study aims to test and provide empirical evidence of the accuracy of moving average technical analysis in predicting the direction of stock price movement of LQ45 stocks at the Jakarta Stock Exchange. In order to meet the objective of this research, sample of 37 stocks were collected with purposive sampling technique. Stocks that were selected as sample were stock those that experienced Golden Cross and Death Cross during observation period, February to July 2019. Data were collected through Esmart application. To test the research hypothesis, the statistical differences between the predictions and the reality of stock price movement were tested using Mann-Whitney non-parametric test. This study found that there is no statistical difference between the predictions and the reality of stock price movement. Thus, this study provides empirical evidence of the accuracy of moving average in predicting the direction of stock price movement of LQ45 stocks at the Jakarta Stock Exchange. The finding of this study can be used as a reference for the investor in selecting appropriate technical analysis method that can assist them in making sound investment decisions.
\end{abstract}

Keywords: Technical Analysis; Accuracy of Moving Average; Stock; Investment Decision 


\section{PENDAHULUAN}

Di masa kini, masyarakat memiliki pemikiran yang terbuka akan investasi. Tujuannya tidak lain mengharapkan hasil di masa yang akan datang. Investasi adalah komitmen atas sejumlah dana atau sumber daya lainnya yang dilakukan saat ini dengan tujuan memperoleh sejumlah keuntungan dimasa yang akan datang ( Tandelilin, 2010; Putri \& Mesrawati, 2020). Investasi juga diharapkan dapat meningkatkan kesejahteraan masyarakat baik di masa sekarang maupun masa mendatang (hartono, 2018).

Terdapat beberapa jenis investasi, antara lain: investasi emas, properti, deposito, obligasi, reksadana, maupun saham. Untuk memperoleh imbal hasil yang tinggi, sebagian investor melakukan investasi melalui pasar modal. Pasar modal adalah tempat bertemunya pihak yang butuh modal, dengan pihak yang ingin berinvestasi pada produk keuangan (Mumpuni, 2017). Salah satu pilihan investasi di pasar modal yang cukup dikenal masyarakat adalah saham.

Saham adalah tanda penyertaan modal seseorang atau pihak (badan usaha) dalam suatu perusahaan atau perseroan terbatas. Dengan menyertakan modal tersebut, maka pihak tersebut memiliki klaim atas pendapatan perusahaan, klaim atas aset perusahaan dan berhak hadir dalam Rapat Umum Pemegang Saham (RUPS). Ada beberapa keunggulan investasi saham yaitu saham sangat mudah ditransaksikan, saham bersifat likuid dan transparan, transaksi saham dapat dilakukan dimana saja, modal investasi relatif kecil, hasil investasi relatif tinggi, administrasi dan pajak yang mudah, dapat dilakukan hingga tua dan dapat diwariskan (Mumpuni, 2017)

Terdapat dua keuntungan investasi saham yaitu capital gain dan dividen. Capital gain merupakan keuntungan yang diperoleh dari selisih antara harga beli dan harga jual. Dividen adalah pembagian keuntungan yang diberikan perusahaan dan berasal dari keuntungan yang dihasilkan perusahaan. Dividen diberikan setelah mendapat persetujuan dari pemegang saham dalam rapat umum pemegang saham (www.idx.co.id, 2019).

Dengan banyaknya perusahaan yang tercatat di Bursa Efek Indonesia (BEI), untuk memudahkan investor dalam memilih saham maka BEI menerbitkan beberapa indeks antara lain Indeks Saham Syariah Indonesia (ISSI), Indeks BISNIS-27, Indeks PEFINDO25, Indeks Kompas 100, Jakarta Islamic Index (JII), Indeks SRI-KEHATI, IDX 30 dan Indeks LQ 45.

Penelitian ini berfokus pada saham-saham LQ-45 di Bursa Efek Indonesia periode Pebruari-Juli 2019. LQ-45 adalah indeks yang mengukur kinerja 45 saham yang memiliki likuiditas tinggi dan kapitalisasi pasar besar serta didukung oleh fundamental perusahaan yang baik (www.idx.co.id, n.d.). Saham-saham LQ45 dikatagorikan sebagai saham yang baik untuk pilihan investasi saham, karena harganya stabil dan memiliki risiko yang relatif lebih rendah dibandingkan saham perusahaan yang likuiditasnya rendah dan memiliki kapitalisasi pasar yang kecil. Saham perusahaan yang masuk dalam LQ45 memiliki jumlah saham beredar 
banyak dan volume perdagangan tinggi, sehingga permintaan-penawaran dan jumlah lot yang diperdagangkan setiap harinya pasti ada.

Investor saham dalam menginvestasikan dananya tentunya mengharapkan return yang lebih tinggi dibandingkan jenis investasi lainnya. Untuk itu investor seringkali dihadapkan pada keputusan untuk melakukan pembelian dan atau penjualan saham dalam waktu singkat. Dalam mengambil keputusan untuk membeli dan menjual saham, investor memerlukan analisis yang tepat.

Terdapat dua tipe analisis yang bisa digunakan oleh investor dalam berinvestasi saham yaitu analisis fundamental dan analisis teknikal. Analisis fundamental memanfaatkan laporan keuangan dan data-data keuangan perusahaan untuk meramalkan prospek pertumbuhan perusahaan (Widoatmodjo, 2015). Analisis fundamental juga memanfaatkan berbagai informasi yang berkaitan dengan kesehatan perusahaan, manajemen perusahaan, pesaing, dan situasi pasar dari produk/jasa perusahaan tersebut (May, 2011). (Atmaja, 2011) menyatakan, analisis fundamental mempelajari hal-hal yang berkaitan dengan kondisi dasar (fundamental) perusahaan baik secara kualitatif (non-keuangan) maupun secara kuantitatif (keuangan). Analisis fundamental didasarkan pada bahwa suatu waktu harga saham akan menyimpang dari nilai intrinsiknya, jika harga saham di bawah nilai intrinsiknya maka saham dikatakan undervalued sehingga layak beli, sebaliknya jika harga saham diatas nilai intrinsiknya maka saham dikatakan overvalued sehingga layak jual (Zakamulin, 2017). (Burns et al., 2015) menyatakan bahwa ketika analisis fundamental berfokus pada valuasi perusahaan dimana mayoritas berfokus pada earnings ratio, sales growth, earnings growth, analisis teknikal justru mempelajari perilaku dari pelaku pasar dan melihat pergerakan harga untuk menentukan level harga untuk membeli dan menjual saham.

Analisis teknikal adalah suatu metode pengevaluasian saham, komoditas, ataupun sekuritas lainnya dengan cara menganalisis statistik yang dihasilkan oleh aktivitas pasar di masa lampau guna memprediksikan pergerakan harga di masa mendatang (Ong, 2016). Investor juga dapat mengamati perubahan harga dan volume perdagangan untuk pengambilan keputusan membeli maupun menjual saham (Asthri, 2016; Putri \& Mesrawati, 2020). Analisis teknikal menggunakan grafik-grafik untuk membaca perilaku pasar melalui pergerakan harga saham dan mengevaluasi pergerakan harga serta memprediksi kecenderungan harga di masa mendatang dalam rentang waktu pendek, menengah, dan panjang (May, 2011; Baining, 2017). (Zakamulin, 2017) berpendapat bahwa salah satu prinsip dasar analisis teknikal adalah bahwa pola harga tertentu secara konsisten muncul kembali dan cenderung untuk menghasilkan hasil yang sama.

Terdapat empat pilar analisis teknikal menurut (Kahn, 2010) yaitu harga, volume, time, sentiment. Harga merupakan bagian yang terpenting dalam analisis teknikal untuk mengukur keuntungan dan kerugian dalam selisih beli dan jual. Volume meliputi konsep-konsep seperti akumulasi, distribusi, luasnya pasar, minat terbuka dan jumlah perdagangan. Time meliputi siklus, hubungan antara pola dan trends dari sudut pandang durasi. Yang terakhir adalah sentiment dimana merupakan area yang lebih subyektif dalam menentukan perkiraan investor. 
Analisis teknikal beranggapan bahwa harga suatu saham ditentukan oleh penawaran dan permintaan terhadap saham tersebut (Halim, 2015). Selain itu, terdapat tiga pemikiran yang menjadi dasar analisis teknikal, yaitu: 1. Pergerakan harga yang terjadi di pasar telah mewakili seluruh informasi relevan; 2 . Terdapat suatu pola kecenderungan dalam pergerakan harga; 3. Sejarah pergerakan saham akan terulang (Ong, 2016). Menurut (Kahn, 2010) salah satu komponen dasar analisis teknikal adalah grafik. (Kahn, 2010) juga menyebutkan bahwa grafik merupakan alat yang memungkinkan investor untuk melihat peluang dan melihat dengan cepat kapan saatnya untuk merubah strategi dalam memutuskan untuk membeli, untuk menjual atau untuk hold. Alat analisis teknikal lainnya adalah indikator. Indikator merupakan alat yang menganalisis harga menggunakan rumus dan mendukung investor dalam pengambilan keputusan melalui evaluasi visual langsung pada grafik (Schlotmann et al., 2019)

Terdapat banyak indikator dalam analisis teknikal antara lain Stochastic, Bollinger Bands, Moving Average Convergence Divergence, parabolic sar dan Moving Average (MA) (Ong, 2016). Indikator moving average bisa digunakan secara mandiri maupun digunakan bersama dengan indikator teknikal lainnya yaitu moving average convergence divergence, dan relative strength index (Burns et al., 2015). Indikator MA paling luas dan merupakan indikator paling popular yang digunakan oleh para technicalist karena sangat mudah digunakan dan dianalisis (Ong, 2016; Schlotmann et al., 2019) dan merupakan salah satu alat analisis terbaik (Burns et al., 2015). Pada trend naik, harga saham cenderung tetap diatas garis moving average, sebaliknya pada trend turun, harga saham cenderung dibawah garis moving average (Burns et al., 2015). Beberapa penelitian sebelumnya (de Souza et al., 2018; Han et al., 2013; Ko et al., 2014; Mahalanie, 2016) mengindikasikan bahwa strategi MA memberikan imbal hasil yang lebih tinggi dibandingkan dengan strategi buy and hold.

MA merupakan nilai rata-rata pergerakan harga dalam rentang waktu tertentu untuk mengetahui trend (May, 2011; Parama Asthri, 2016). MA trading mengacu pada praktik pembelian dan penjualan secara sistematis kapan saja harga melintasi rata-rata (Toms, 2011). Harga rata-rata penting karena menunjukkan harga saat ini diatas atau dibawah rata-rata dan menunjukkan apakah murah atau mahal dibandingkan dengan harga masa lalu (Schlotmann et al., 2019) Moving average merupakan panduan yang baik untuk menentukan waktu beli dan jual saham. MA juga dapat menunjukkan kepada traders dan investors perilaku jual beli di pasar. MA dapat digunakan untuk mengidentifikasi trend pergerakan harga saham. MA juga dapat digunakan untuk mengukur keputusan perdagangan saat ini berdasarkan pada tren harga sebelumnya. MA dapat menjadi bagian dalam trading plan dan trading systems (Burns et al., 2015). Terdapat 3 jenis MA (Ong, 2016), yaitu Simple Moving Average (SMA), Weighted Moving Average (WMA), Exponential Moving Average (EMA).

Widodo dan Hansun (2016) menemukan bahwa EMA memiliki level akurasi lebih tinggi dibandingkan SMA. EMA memiliki bobot yang lebih besar dibandingkan SMA, sehingga EMA lebih reaktif dan lebih cepat dalam penyesuaian dengan harga saham (Burns et al., 2015). Penelitian Kresta dan Franek (2015) menemukan bahwa sistem yang didasarkan pada titik potong dari 
dua garis MA (disebut metode double crossover moving average) akan menghasilkan rekomendasi keputusan investasi yang menguntungkan.

Pengaturan periode waktu suatu MA antara lain : 1. MA 10 (rata-rata pergerakan 10 hari). Dalam periode ini popular digunakan karena MA bereaksi cepat terhadap perubahan harga. 2. MA 20 ( rata-rata pergerakan 20 hari) merupakan kisaran MA jangka menengah. 3. MA 50 (rata-rata pergerakan 50 hari) merupakan salah satu periode MA yang populer digunakan oleh traders.4. MA 100/200 (rata-rata pergerakan 100/200 hari) merupakan MA yang digunakan untuk jangka waktu yang lebih panjang (Schlotmann, 2019).

Kombinasi untuk perdagangan saham jangka pendek umumnya menggunakan MA 10 (rata-rata pergerakan harga 10 hari) dan MA 50 (rata-rata pergerakan harga 50 hari) (Ong, 2016). Ong (2016) juga menjelaskan cara membaca sinyal pada metode double crossover, yaitu dengan memperhatikan perpotongan yang terjadi antara kedua garis MA tersebut. Jika garis MA periode pendek memotong ke atas garis MA yang memiliki periode lebih panjang (sering disebut Golden Cross), maka memberikan sinyal kenaikan harga/bullish. Sebaliknya, bila garis MA periode pendek tersebut memotong ke bawah garis MA yang memiliki periode lebih panjang (sering disebut Death Cross), maka memberikan sinyal penurunan harga/bearish. May (2011) lebih lanjut menjelaskan Golden Cross menunjukkan sinyal beli dengan prediksi harga saham akan naik. Sebaliknya, Death Cross menunjukkan sinyal jual dengan prediksi harga saham akan turun.

Berbeda dengan penelitian yang mengindikasikan keunggulan strategi MA dalam memberikan imbal hasil yang lebih tinggi (de Souza et al., 2018; Han et al., 2013; Ko et al., 2014; Mahalanie, 2016), penelitian oleh Baining (2017) justru menunjukkan bahwa penggunaan indikator bollinger bands memberi hasil yang lebih optimal dibandingkan dengan indikator MA dan relative strength index. Senada dengan Baining (2017), penelitian oleh Prasetyo (2019) mengindikasikan bahwa indikator MA convergence divergence menghasilkan profit yang lebih besar dibandingkan dengan indikator stochastic dan MA.

Penelitian-penelitian sebelumnya telah memperkaya wawasan akan kelebihan dan kekurangan serta keunggulan salah satu metode analisis teknikal jika dibandingkan metode lainnya. Akan tetapi masih sedikit sekali penelitian yang secara khusus dan mendalam menguji keakuratan metode Moving Average (MA) dalam memprediksi harga saham. Dengan demikian, penelitian ini bertujuan untuk mengisi gap dalam literatur dengan memberikan bukti empiris terkait akurasi metode MA dalam memprediksi harga saham. Selain mengisi gap dalam literatur terkait bukti empiris akurasi metode MA, penelitian ini juga diharapkan akan menjadi referensi berharga bagi investor pasar modal dalam menentukan metode analisis teknikal yang lebih akurat dalam membantu pengambilan keputusan investasi.

Untuk mencapai tujuan penelitian, pertanyaan penelitian ini adalah, apakah metode MA akurat dalam memprediksi harga saham? Terdapat dua hipotesis yang diajukan dalam penelitian ini, yaitu:

Ho: Tidak terdapat perbedaan antara prediksi harga dan kenyataan dengan menggunakan indikator moving average (akurat) 
$\mathrm{H}_{1}$ : Terdapat perbedaan antara prediksi harga dan kenyataan dengan menggunakan indikator moving average (tidak akurat).

\section{METODE PENELITIAN}

Untuk menjawab hipotesis penelitian, dilakukan uji nonparametrik dengan Mann Whitney test yang dapat membuktikan secara statistik mengenai ada atau tidaknya perbedaan antara prediksi dengan kenyataan harga saham. Data diperoleh melalui chart pada aplikasi yang dimiliki PT. BNI Sekuritas yaitu esmart. Saham yang dianalisis dalam penelitian ini adalah saham LQ45 yang mengalami golden cross dan death cross selama periode Pebruari-Juli 2019.

Golden cross adalah perpotongan garis MA dimana garis MA pendek (MA10) memotong keatas garis MA yang lebih panjang (MA50). Death cross adalah perpotongan garis MA dimana garis MA pendek (MA10) memotong kebawah garis MA yang lebih panjang (MA50). Data yang dianalisis adalah data harga penutupan pada saat terjadinya golden cross maupun death cross dibandingkan dengan harga penutupan satu hari setelah golden cross maupun death cross tersebut terjadi. Gambar 1. menunjukkan salah satu saham yang mengalami golden cross dan death cross. Garis yang berwarna biru menunjukkan MA pendek (MA10) sedangkan garis berwarna merah menunjukkan MA panjang (MA50).

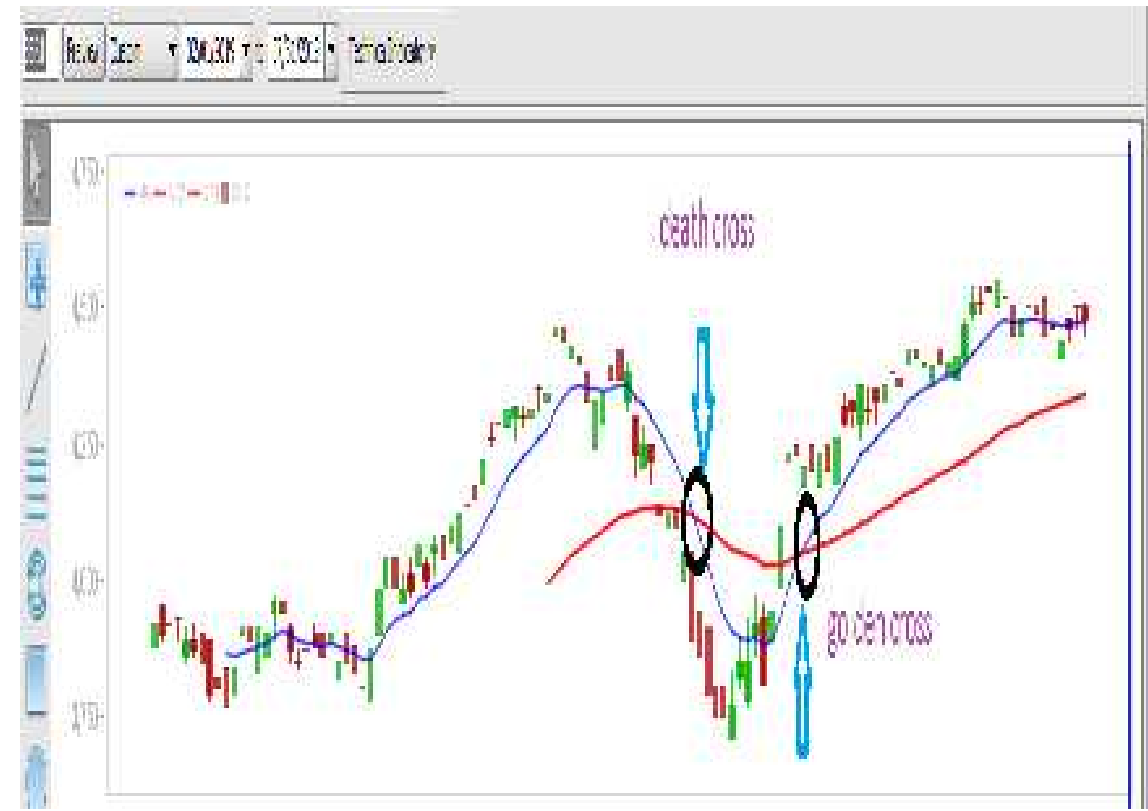

Gambar 1. Grafik Penunjuk Terjadinya Death Cross dan Golden Cross Sumber: esmart, 2019

Pada gambar tersebut tampak bahwa jika garis MA pendek memotong kebawah garis MA panjang maka harga saham cenderung bergerak turun. Sebaliknya jika garis MA pendek memotong keatas garis MA panjang, maka harga saham cenderung bergerak naik.

Berdasarkan kriteria tersebut maka diperoleh data perusahaan LQ 45 periode Pebruari-Juli 2019 yang menunjukkan death cross sebagaimana ditampilkan dalam Tabel 1. berikut. 
Tabel 1.

Data Perusahaan yang Menunjukkan Death Cross

\begin{tabular}{cll}
\hline No & \multicolumn{1}{c}{ Nama Perusahaan } & $\begin{array}{c}\text { Kode } \\
\text { Saham }\end{array}$ \\
\hline 1. & Adhi Karya (Persero) Tbk & ADHI \\
2. & Adaro Energy Tbk & ADRO \\
3. & Astra International Tbk & ASII \\
4. & Bank Central Asia Tbk & BBCA \\
5. & Bank Negara Indonesia (Persero) Tbk & BBNI \\
6. & Bank Rakyat Indonesia (Persero) Tbk & BBRI \\
7. & Bank Tabungan Negara (Persero) Tbk & BBTN \\
8. & Bank Mandiri (Persero) Tbk & BMRI \\
9. & Barito Pacific Tbk & BRPT \\
10. & Bumi Serpong Damai Tbk & BSDE \\
11. & Elnusa Tbk & ELSA \\
12. & Vale Indonesia Tbk & INCO \\
13. & Indika Energy Tbk & INDY \\
14. & Indah Kiat Pulp \& Paper Tbk \\
15. & Indocement Tunggal Prakasa Tbk & INTP \\
16. & Jasa Marga (Persero) Tbk & JSMR \\
17. & Kalbe Farma Tbk & KLBF \\
18. & PP ( Persero) Tbk & PTPP \\
19. & Pakuwon Jati Tbk & PWON \\
20. & Surya Citra Media Tbk & SCMA \\
21. & Semen Indonesia (Persero) Tbk & SMGR \\
22. & Telekomunikasi Indonesia(Persero) Tbk & TLKM \\
23. & United Tractors Tbk & UNTR \\
24. & Unilever Indonesia Tbk & UNVR \\
25. & Wijaya Karya (Persero) Tbk & WIKA \\
26. & Waskita Beton Precast Tbk & WTON \\
27. & Waskita karya (Persero) Tbk & WSKT \\
\hline Sumber: esmart, 2019 &
\end{tabular}

Dari 45 saham pengamatan, diperoleh data saham yang mengalami death cross sebanyak 27 saham.

Untuk data-data perusahaan LQ45 periode Pebruari-Juli 2019 yang menunjukkan golden cross ditampilkan pada Tabel 2.

\section{Tabel 2.}

Data Perusahaan Menunjukkan Golden Cross

\begin{tabular}{cll}
\hline No & \multicolumn{1}{c}{ Nama Perusahaan } & Kode Saham \\
\hline 1. & Adhi Karya (Persero) Tbk & ADHI \\
2. & Adaro Energy Tbk & ADRO \\
3. & Aneka Tambang Tbk & ANTM \\
4. & Astra International Tbk & ASII \\
5. & Bank Central Asia Tbk & BBCA \\
6. & Bank Negara Indonesia (Persero) Tbk & BBNI \\
7. & Bank Rakyat Indonesia (Persero) Tbk & BBRI \\
8. & Bank Tabungan Negara (Persero) Tbk & BBTN \\
\hline
\end{tabular}

Bersambung... 


\begin{tabular}{|c|c|c|}
\hline No & Nama Perusahaan & $\begin{array}{l}\text { Kode } \\
\text { Saham }\end{array}$ \\
\hline 9. & Bank Mandiri (Persero) Tbk & BMRI \\
\hline 10. & Barito Pacific Tbk & BRPT \\
\hline 11. & Bumi Serpong Damai Tbk & BSDE \\
\hline 12. & Charoen Pokhpand Indonesia Tbk & CPIN \\
\hline 13. & Elnusa Tbk & ELSA \\
\hline 14. & Erajaya Swasembada Tbk & ERAA \\
\hline 15. & Indofood CBP Sukses Makmur Tbk & ICBP \\
\hline 16. & Vale Indonesia Tbk & INCO \\
\hline 17. & Indofood Sukses Makmur Tbk & INDF \\
\hline 18. & Indika Energy Tbk & INDY \\
\hline 19. & Indah Kiat Pulp \& Paper Tbk & INKP \\
\hline 20. & Indocement Tunggal Prakasa Tbk & INTP \\
\hline 21. & Jasa Marga (Persero) Tbk & JSMR \\
\hline 22. & Kalbe Farma Tbk & KLBF \\
\hline 23. & Medco Energi Internasional Tbk & MEDC \\
\hline 24. & Media Nusantara Citra Tbk & MNCN \\
\hline 25. & PP (Persero) Tbk & PTPP \\
\hline 26. & Pakuwon Jati Tbk & PWON \\
\hline 27. & Surya Citra Media Tbk & SCMA \\
\hline 28. & Semen Indonesia (Persero) Tbk & SMGR \\
\hline 29. & Sri Rejeki Isman Tbk & SRIL \\
\hline 30. & Pabrik Kertas Tjiwi Kimia Tbk & TKIM \\
\hline 31. & Telekomunikasi Indonesia (Persero) Tbk & TLKM \\
\hline 32. & Chandra Asri Petrochemical Tbk & TPIA \\
\hline 33. & United Tractors Tbk & UNTR \\
\hline 34. & Wijaya Karya (Persero) Tbk & WIKA \\
\hline 35. & Waskita Beton Precast Tbk & WSBP \\
\hline 36. & Waskita Karya (Persero) Tbk & WSKT \\
\hline
\end{tabular}

Sumber: esmart, 2019

Dari 45 saham pengamatan, diperoleh sebanyak 36 saham yang mengalami golden cross.

Sampel penelitian ini meliputi 37 total saham yaitu ADHI, ADRO, ANTM, ASII, BBCA,BBNI, BBRI, BBTN, BMRI, BRPT, BSDE, CPIN, ELSA, ERAA, ICBP, INCO, INDF, INDY, INKP, INTP, JSMR, KLBF, MEDC, MNCN, PTPP, PWON, SCMA, SMGR, SRIL, TKIM, TLKM, TPIA, UNTR, UNVR, WIKA, WSBP, WSKT.

Berikut adalah penjelasan langkah-langkah yang ditempuh untuk melakukan analisis dalam penelitian ini. Pertama, mendata perusahaan yang menunjukkan sinyal golden cross dan death cross. Kedua, melakukan pembandingan antara prediksi arah perubahan harga saham dan kenyataan yang menggunakan harga penutupan saat terjadinya golden cross atau death cross dan harga penutupan hari bursa berikutnya. Chart yang menunjukkan harga penutupan saat terjadinya death cross ditunjukkan pada Gambar 2. 


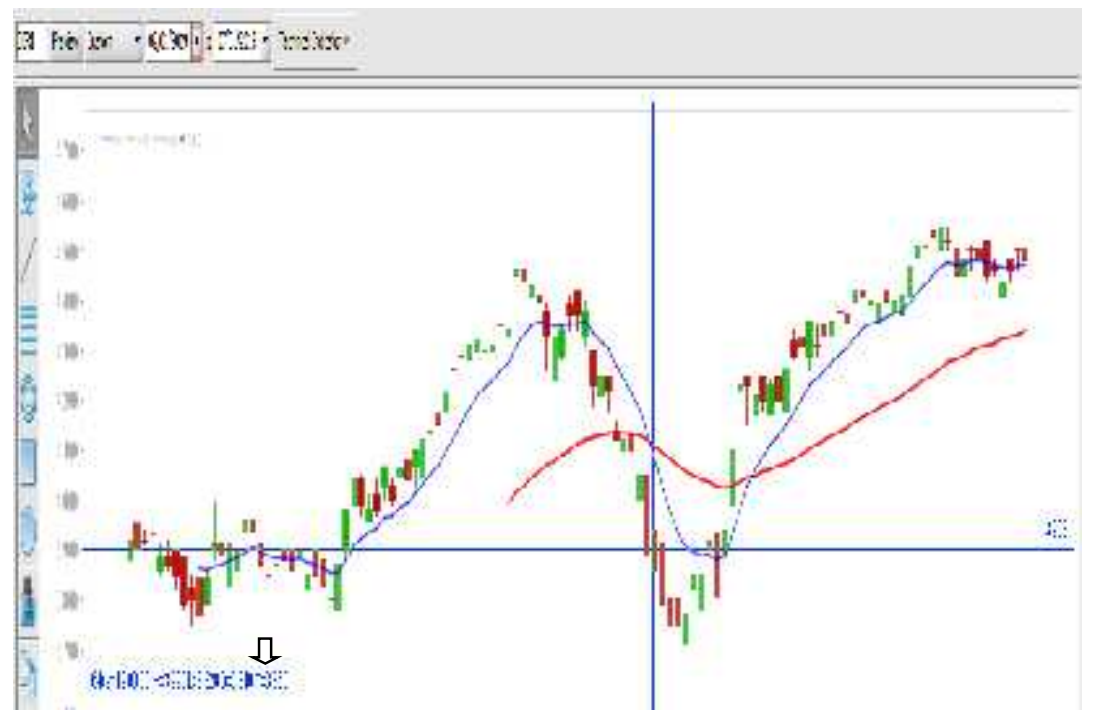

Gambar 2. Gambar penunjuk harga close saat terjadi nya death cross

Sumber : esmart, 2019

Pada Gambar 2. dapat dijelaskan bahwa harga penutupan saat terjadi nya death cross adalah Rp. 3.860. Kemudian dibandingkan dengan harga close hari bursa berikutnya sebagaimana ditunjukkan dalam Gambar 3.

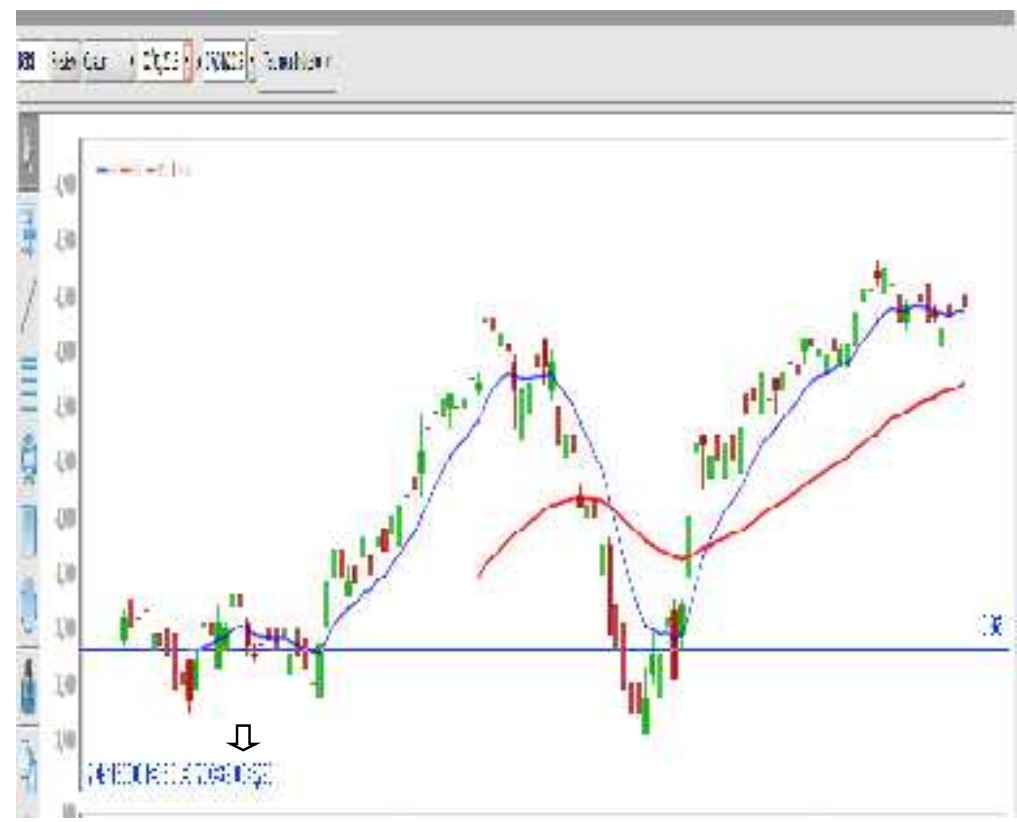

\section{Gambar 3. Gambar penunjuk harga close setelah terjadinya death cross}

Sumber : esmart, 2019

Pada gambar tersebut tampak bahwa harga close setelah terjadinya death cross adalah Rp.3.790. Demikian pula untuk harga penutupan saat terjadinya golden cross ditunjukkan dalam Gambar 4. 


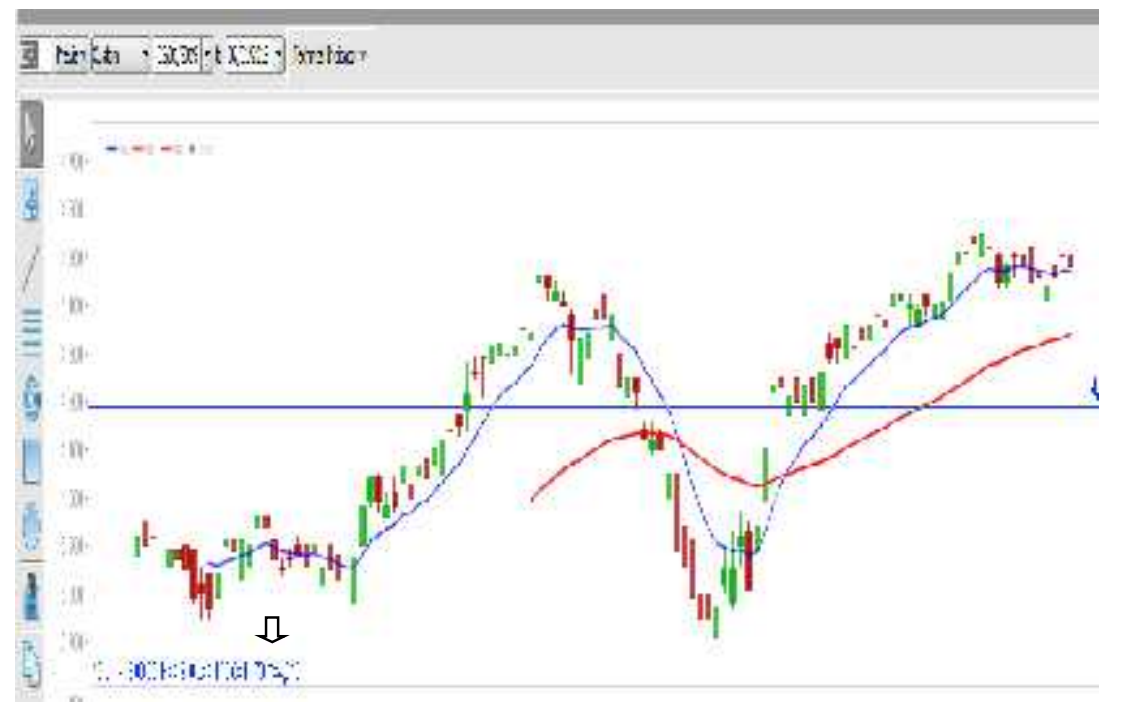

Gambar 4. Gambar penunjuk harga close saat terjadinya golden

Sumber: esmart, 2019 cross

Pada Gambar 4. dapat dijelaskan bahwa harga close yang terbentuk pada hari terjadinya golden cross adalah di harga Rp.4.210. Sedangkan chart yang menunjukkan harga close setelah terjadinya golden cross ditampilkan pada Gambar 5.

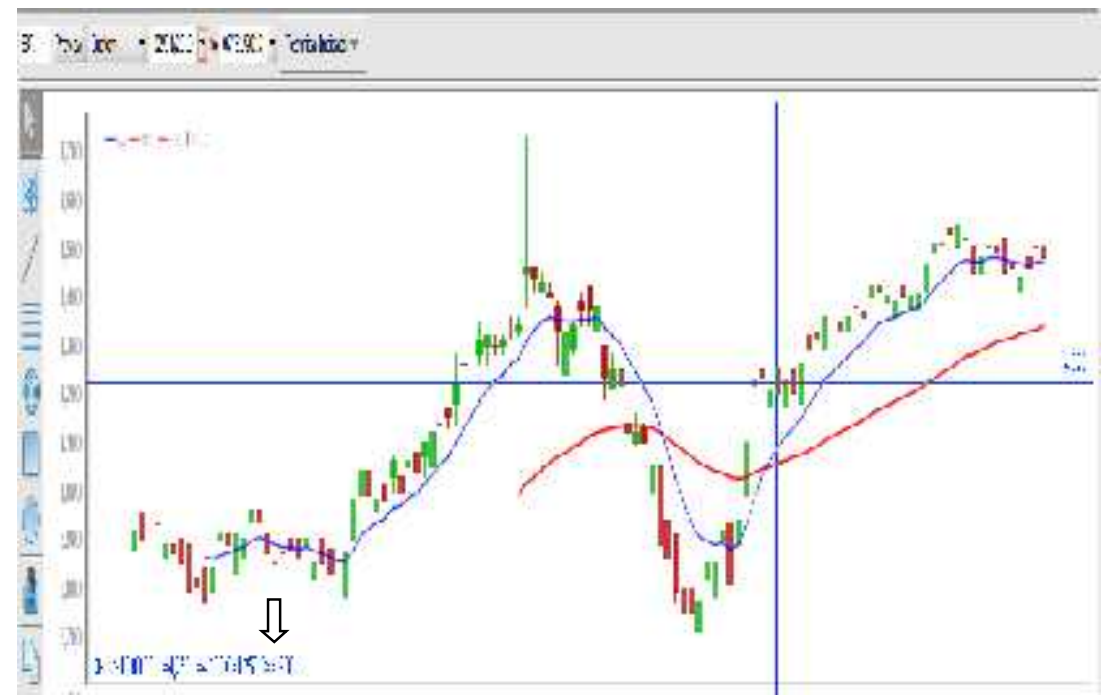

Gambar 5. Gambar penunjuk harga close setelah terjadinya golden cross

Sumber: esmart, 2019

Pada Gambar 5. dapat dijelaskan bahwa harga close setelah terjadinya golden cross adalah Rp. 4.200.

Untuk memudahkan analisis maka antara prediksi dan kenyataan diberikan kode unik dimana jika naik diberi kode 1, jika turun diberi kode 2 dan jika tetap diberi kode 3. Hal tersebut ditunjukkan dalam Tabel 3 dimana CP adalah Coding Prediksi dan CK adalah Coding kenyataan. 
Tabel 3.

Data Perbandingan Prediksi Arah Perubahan Harga Saham Golden Cross dan Kenyataan

\begin{tabular}{|c|c|c|c|c|c|}
\hline No & Saham & Prediksi & $\mathbf{C P}$ & Kenyataan & CK \\
\hline 1. & ADHI & Naik & 1 & Turun & 2 \\
\hline 2. & ADRO & Naik & 1 & Naik & 1 \\
\hline 3. & ANTM & Naik & 1 & Naik & 1 \\
\hline 4. & ASII & Naik & 1 & Turun & 2 \\
\hline 5. & BBCA & Naik & 1 & Naik & 1 \\
\hline 6. & BBNI & Naik & 1 & Naik & 1 \\
\hline 7. & BBRI & Naik & 1 & Turun & 2 \\
\hline 8. & BBTN & Naik & 1 & Naik & 1 \\
\hline 9. & BMRI & Naik & 1 & Naik & 1 \\
\hline 10. & BRPT & Naik & 1 & Turun & 2 \\
\hline 11. & BSDE & Naik & 1 & Naik & 1 \\
\hline 12. & CPIN & Naik & 1 & Naik & 1 \\
\hline 13. & ELSA & Naik & 1 & Turun & 2 \\
\hline 14. & ERAA & Naik & 1 & Naik & 1 \\
\hline 15 & ICBP & Naik & 1 & Naik & 1 \\
\hline 16. & INCO & Naik & 1 & Naik & 1 \\
\hline 17. & INDF & Naik & 1 & Naik & 1 \\
\hline 18. & INDY & Naik & 1 & Turun & 2 \\
\hline 19. & INKP & Naik & 1 & Naik & 1 \\
\hline 20. & INTP & Naik & 1 & Turun & 2 \\
\hline 21. & JSMR & Naik & 1 & Tetap & 3 \\
\hline 22. & KLBF & Naik & 1 & Naik & 1 \\
\hline 23. & MEDC & Naik & 1 & Naik & 1 \\
\hline 24. & MNCN & Naik & 1 & Naik & 1 \\
\hline 25. & PTPP & Naik & 1 & Naik & 1 \\
\hline 26. & PWON & Naik & 1 & Naik & 1 \\
\hline 27. & SCMA & Naik & 1 & Turun & 2 \\
\hline 28. & SMGR & Naik & 1 & Tetap & 3 \\
\hline 29 & SRIL & Naik & 1 & Tetap & 3 \\
\hline 30. & TKIM & Naik & 1 & Naik & 1 \\
\hline 31. & TLKM & Naik & 1 & Turun & 2 \\
\hline 32. & TPIA & Naik & 1 & Naik & 1 \\
\hline 33. & UNTR & Naik & 1 & Naik & 1 \\
\hline 34. & WIKA & Naik & 1 & Naik & 1 \\
\hline 35. & WSBP & Naik & 1 & Naik & 1 \\
\hline 36 & WSKT & Naik & 1 & Turun & 2 \\
\hline
\end{tabular}

Kode unik untuk data yang menunjukkan death cross dimana jika naik diberi kode 1, jika turun diberi kode 2 dan jika tetap diberi kode 3 juga ditunjukkan dalam Tabel 4. dimana $\mathrm{CP}$ adalah coding prediksi dan $\mathrm{CK}$ adalah coding kenyataan.

Tabel 4.

Data Perbandingan Prediksi Arah Perubahan Harga Saham Death Cross dan Kenyataan

\begin{tabular}{cccccc}
\hline No & Saham & Prediksi & CP & Kenyataan & CK \\
\hline 1. & ADHI & Turun & 2 & Tetap & 3 \\
\hline Bersambung... & & & &
\end{tabular}




\begin{tabular}{|c|c|c|c|c|c|}
\hline No & Saham & Prediksi & $\mathbf{C P}$ & Kenyataan & CK \\
\hline 2. & ADRO & Turun & 2 & Turun & 2 \\
\hline 3. & ASII & Turun & 2 & Turun & 2 \\
\hline 4. & BBCA & Turun & 2 & Turun & 2 \\
\hline 5. & BBNI & Turun & 2 & Turun & 2 \\
\hline 6. & BBRI & Turun & 2 & Turun & 2 \\
\hline 7. & BBTN & Turun & 2 & Turun & 2 \\
\hline 8. & BMRI & Turun & 2 & Naik & 1 \\
\hline 9. & BRPT & Turun & 2 & Tetap & 3 \\
\hline 10. & BSDE & Turun & 2 & Naik & 1 \\
\hline 11. & ELSA & Turun & 2 & Turun & 2 \\
\hline 12. & INCO & Turun & 2 & Naik & 1 \\
\hline 13. & INDY & Turun & 2 & Turun & 2 \\
\hline 14. & INKP & Turun & 2 & Turun & 2 \\
\hline 15. & INTP & Turun & 2 & Naik & 1 \\
\hline 16. & JSMR & Turun & 2 & Turun & 2 \\
\hline 17. & KLBF & Turun & 2 & Turun & 2 \\
\hline 18. & РTPP & Turun & 2 & Turun & 2 \\
\hline 19. & PWON & Turun & 2 & Tetap & 3 \\
\hline 20. & SCMA & Turun & 2 & Turun & 2 \\
\hline 21. & SMGR & Turun & 2 & Turun & 2 \\
\hline 22. & TLKM & Turun & 2 & Turun & 2 \\
\hline 23. & UNTR & Turun & 2 & Tetap & 3 \\
\hline 24. & UNVR & Turun & 2 & Turun & 2 \\
\hline 25. & WIKA & Turun & 2 & Naik & 1 \\
\hline 26. & WSBP & Turun & 2 & Turun & 2 \\
\hline 27. & WSKT & Turun & 2 & Turun & 2 \\
\hline
\end{tabular}

Sumber : esmart, 2019

Ketiga, melakukan uji beda non parametrik dengan uji Mann-Whitney untuk mengetahui apakah terdapat perbedaan secara statistik dari dua sampel data yang independen. Hipotesis yang digunakan dalam penelitian adalah

Ho: Tidak terdapat perbedaan antara prediksi harga dan kenyataan dengan menggunakan indikator moving average (akurat)

$\mathrm{H}_{1}$ : Terdapat perbedaan antara prediksi harga dan kenyataan dengan menggunakan indikator moving average (tidak akurat).

Kriteria pengujiannya adalah apabila nilai signifikansi (Asym Sig 2-tailed kurang dari $\alpha=0,05$ maka Ho ditolak dan H1 diterima dengan kesimpulan terdapat perbedaan antara prediksi harga dan kenyataan. Sebaliknya apabila nilai signifikansi lebih besar dari $\alpha=0,05$ maka Ho diterima dan $\mathrm{H} 1$ ditolak dengan kesimpulan tidak terdapat perbedaan antara prediksi harga dan kenyataan.

\section{HASIL DAN PEMBAHASAN}

Dari hasil pengamatan maka diperoleh total 37 saham yang mengalami golden cross maupun death cross selama periode amatan. Dari 37 saham tersebut saham yang mengalami golden cross saja yaitu ANTM, CPIN, ERAA, ICBP, INDF, MEDC, MNCN, SRIL, TKIM, dan TPIA. Saham yang mengalami death cross saja yaitu UNVR dan saham yang mengalami golden cross dan death cross yaitu ADHI, ADRO, ASII, BBCA, BBNI, BBRI, BBTN, BMRI, BRPT, BSDE, 
ELSA, INCO, INDY, INKP, INTP, JSMR, KLBF, PTPP, PWON, SCMA, SMGR, TLKM, UNTR, WIKA dan WSKT. Data saham yang menunjukkan golden cross ditunjukkan dalam Tabel 5.

Tabel 5.

Data Saham yang Menunjukkan Golden Cross (GC)

\begin{tabular}{cccc}
\hline No. & Kode Saham GC & No. & Kode Saham GC \\
\hline 1. & ADHI & 19. & INKP \\
2. & ADRO & 20. & INTP \\
3. & ANTM & 21. & JSMR \\
4. & ASII & 22. & KLBF \\
5. & BBCA & 23. & MEDC \\
6. & BBNI & 24. & MNCN \\
7. & BBRI & 25. & PTPP \\
8. & BBTN & 26. & PWON \\
9. & BMRI & 27. & SCMA \\
10. & BRPT & 28. & SMGR \\
11. & BSDE & 29. & SRIL \\
12. & CPIN & 30. & TKIM \\
13. & ELSA & 31. & TLKM \\
14. & ERAA & 32. & TPIA \\
15. & ICBP & 33. & UNTR \\
16. & INCO & 34. & WIKA \\
17. & INDF & 35. & WSBP \\
18. & INDY & 36. & WSKT \\
\hline
\end{tabular}

Sumber: esmart, 2019

Tabel 6. berikut menunjukkan data saham yang menunjukkan Death Cross.

Tabel 6.

Data saham yang menunjukkan Death Cross

\begin{tabular}{cc}
\hline No. & Kode Saham Death Cross \\
\hline 1. & ADHI \\
2. & ADRO \\
3. & ASII \\
4. & BBCA \\
5. & BBNI \\
6. & BBRI \\
7. & BBTN \\
8. & BMRI \\
9. & BRPT \\
10 & BSDE \\
11. & ELSA \\
12. & INCO \\
13. & INDY \\
14. & INKP \\
15. & INTP \\
16. & JSMR \\
17. & KLBF \\
18. & PTPP \\
\hline
\end{tabular}

Bersambung... 
Lanjutan Tabel 6.

\begin{tabular}{lc}
\hline No & Kode Saham Death Cross \\
\hline 19. & PWON \\
20. & SCMA \\
21. & SMGR \\
22. & TLKM \\
23. & UNTR \\
24. & UNVR \\
25. & WIKA \\
26. & WSBP \\
27. & WSKT \\
\hline
\end{tabular}

Sumber: esmart, 2019

Setelah melihat saham yang mengalami golden cross dan death cross maka selanjutnya dilakukan pencatatan hasil yang diperoleh dari pembandingan antara prediksi dan kenyataan. Data perbandingan prediksi arah perubahan harga saham dan kenyataan saham yang mengalami golden cross ditampilkan dalam Tabel 7.

Tabel 7.

Data Perbandingan Prediksi Arah Perubahan Harga Saham dan Kenyataan Saham Yang Mengalami Golden Cross

\begin{tabular}{cccc}
\hline No & Saham & Prediksi & Kenyataan \\
\hline 1. & ADHI & Naik & Turun \\
2. & ADRO & Naik & Naik \\
3. & ANTM & Naik & Naik \\
4. & ASII & Naik & Turun \\
5. & BBCA & Naik & Naik \\
6. & BBNI & Naik & Naik \\
7. & BBRI & Naik & Turun \\
8. & BBTN & Naik & Naik \\
9. & BMRI & Naik & Naik \\
10. & BRPT & Naik & Turun \\
11. & BSDE & Naik & Naik \\
12. & CPIN & Naik & Naik \\
13. & ELSA & Naik & Turun \\
14. & ERAA & Naik & Naik \\
15. & ICBP & Naik & Naik \\
16. & INCO & Naik & Naik \\
17. & INDF & Naik & Naik \\
18. & INDY & Naik & Turun \\
19. & INKP & Naik & Naik \\
20. & INTP & Naik & Turun \\
21. & JSMR & Naik & Tetap \\
22. & KLBF & Naik & Naik \\
23. & MEDC & Naik & Naik \\
\hline Bersambung... & & &
\end{tabular}


E-Jurnal Manajemen, Vol. 9, No. 7, 2020 : 2769-2789

Lanjutan Tabel 7.

\begin{tabular}{cccc}
\hline No & Saham & Prediksi & Kenyataan \\
\hline 24. & MNCN & Naik & Naik \\
25. & PTPP & Naik & Naik \\
26. & PWON & Naik & Naik \\
27. & SCMA & Naik & Turun \\
28. & SMGR & Naik & Tetap \\
29. & SRIL & Naik & Tetap \\
30. & TKIM & Naik & Naik \\
31 & TLKM & Naik & turun \\
32. & TPIA & Naik & Naik \\
33. & UNTR & Naik & Naik \\
34. & WIKA & Naik & Naik \\
35. & WSBP & Naik & Naik \\
36. & WSKT & Naik & Turun \\
\hline
\end{tabular}

Sumber: esmart, 2019

Dari data tersebut, untuk saham yang mengalami golden cross diperoleh hasil dimana jumlah saham yang berbeda dengan prediksi ada sebanyak 13 saham yaitu ADHI, ASII, BBRI, BRPT, ELSA, INDY, INTP, JSMR, SCMA, SMGR, SRIL, TLKM, dan WSKT.

Sedangkan data perbandingan prediksi arah perubahan harga saham dan kenyataan saham yang mengalami death cross ditampilkan dalam Tabel 8.

Tabel 8.

Data Perbandingan Prediksi Arah Perubahan Harga Saham dan Kenyataan Saham Yang Mengalami Death Cross

\begin{tabular}{cccc}
\hline No & Saham & Prediksi & Kenyataan \\
\hline 1. & ADHI & Turun & Tetap \\
2. & ADRO & Turun & Turun \\
3. & ASII & Turun & Turun \\
4. & BBCA & Turun & Turun \\
5. & BBNI & Turun & Turun \\
6. & BBRI & Turun & Turun \\
7. & BBTN & Turun & Turun \\
8. & BMRI & Turun & Naik \\
9. & BRPT & Turun & Tetap \\
10. & BSDE & Turun & Naik \\
11. & ELSA & Turun & Turun \\
12. & INCO & Turun & Naik \\
13. & INDY & Turun & Turun \\
14. & INKP & Turun & Turun \\
15. & INTP & Turun & Naik \\
\hline Bersambung... & & &
\end{tabular}


Lanjutan Tabel 8.

\begin{tabular}{cccc}
\hline No & Saham & Prediksi & Kenyataan \\
\hline 16. & JSMR & Turun & Turun \\
17. & KLBF & Turun & Turun \\
18. & PTPP & Turun & Turun \\
19. & PWON & Turun & Tetap \\
20. & SCMA & Turun & Turun \\
21. & SMGR & Turun & Turun \\
22. & TLKM & Turun & Turun \\
23. & UNTR & Turun & Tetap \\
24. & UNVR & Turun & Turun \\
25. & WIKA & Turun & Naik \\
26. & WSBP & Turun & Turun \\
27. & WSKT & Turun & turun \\
\hline
\end{tabular}

Sumber : esmart, 2019

Sedangkan untuk saham yang mengalami death cross diperoleh hasil dimana jumlah saham yang tidak sesuai dengan prediksi ada sebanyak 9 saham yaitu ADHI, BMRI, BRPT, BSDE, INCO, INTP, PWON, UNTR, WIKA,

Uji Mann-Whitney dengan menggunakan SPSS 23 dilakukan untuk menguji secara statistik perbedaan antara prediksi arah perubahan harga saham dan kenyataan. Hasil olah data ditunjukkan pada Tabel 9.

Tabel 9.

Hasil Uji Beda Mann-Whitney

\begin{tabular}{|c|c|c|c|c|}
\hline & Group & $\mathrm{N}$ & $\begin{array}{l}\text { Mean } \\
\text { Rank }\end{array}$ & $\begin{array}{l}\text { Sum of } \\
\text { Ranks }\end{array}$ \\
\hline \multirow[t]{3}{*}{ Nilai } & Kenyataan & 63 & 69.00 & 4347.00 \\
\hline & Prediksi & 63 & 58.00 & 3654.00 \\
\hline & Total & 126 & & \\
\hline
\end{tabular}

Test Statistics ${ }^{\text {a }}$

\begin{tabular}{cr} 
& Nilai \\
Mann-Whitney U & 1638.000 \\
Wilcoxon W & 3654.000 \\
Z & -1.907 \\
Asymp. Sig. (2- & \\
tailed & .056 \\
a. Grouping Variable : Group & \\
\hline Sumber: Data diolah
\end{tabular}

Hasil pengolahan data menunjukkan bahwa prediksi mendapatkan nilai ratarata sebesar 58,00 dan untuk kenyataan mendapatkan nilai rata-rata 69,00. Nilai Mann-Whitney yang dihasilkan sebesar 1638 dan nilai signifikansinya sebesar 
0,056. Dari hasil tersebut dapat disimpulkan bahwa nilai signifikan 0,056 >0,05, maka Ho diterima yaitu tidak terdapat perbedaan signifikan antara prediksi dan kenyataan dan $\mathrm{H}_{1}$ ditolak. Hal ini berarti penggunaan analisis teknikal indikator moving average akurat dalam memprediksi arah perubahan atau pergerakan harga saham.

Hasil penelitian ini sesuai dengan teori moving average (May, 2011) dimana jika garis moving average pendek memotong keatas garis moving average yang lebih panjang atau dengan kata lain terjadi golden cross maka harga saham diprediksikan akan bergerak naik. Sebaliknya jika garis moving average pendek memotong ke bawah garis moving average yang lebih panjang atau terjadi death cross maka diprediksi harga saham akan turun. Penelitian ini memberikan bukti empiris bahwa tidak terjadi perbedaan signifikan antara prediksi arah pergerakan harga dengan kenyataan, jika prediksi dilakukan dengan menggunakan analisis teknikal indikator moving average.

Hasil penelitian ini memperkuat penelitian sebelumnya (Ardani, Murhadi, \& Marciano, 2011) yang menganalisis keefektifan dari analisis teknikal di bursa efek Indonesia dengan menggunakan metode moving average/MA yang dibandingkan dengan buy and hold strategy. Penelitian tersebut membuktikan bahwa analisis teknikal dengan menggunakan metode moving average lebih efektif digunakan dibandingkan dengan buy and hold strategy. Obyek penelitian tersebut adalah saham-saham LQ45 yang mewakili pasar negara berkembang. Penelitian ini juga mendukung beberapa penelitian sebelumnya (Raudys \& Pabarškaite,, 2018; Zakamulin, 2015) yang menyatakan bahwa analisis teknikal dengan menggunakan metode moving average paling unggul dibandingkan metode lainnya. Keunggulan dan keakuratan metode moving average dibandingkan relative strength index juga dibuktikan oleh penelitian lain (Shellina Dessy, 2008).

Moving average memberikan sinyal beli dan sinyal jual, dan terbukti memberikan sinyal lebih awal dan dapat memberikan pengembailan rata-rata yang lebih besar dibandingkan dengan strategi buy and hold. (Glabadanidis, 2015; Marshall, Nguyen, \& Visaltanachoti, 2017). Hal ini senada dengan hasil yang diperoleh peneliti dimana moving average akurat untuk memprediksi pergerakan harga saham.

Beberapa penelitian sebelumnya telah berhasil membuktikan keunggulan analisis teknikal dengan menggunakan metode moving average, hal ini selaras dengan temuan penelitian ini. Akan tetapi, terdapat beberapa penelitian yang menemukan hasil berlawanan. Penelitian-penelitian tersebut (Ahmed et al., 2018; Zhu et al., 2015) (Nugraheni, 2019) menemukan bahwa strategi moving average semakin buruk kinerjanya jika jangka waktu pengamatan yang digunakan semakin panjang. Sebaliknya, berbagai metode yang berbeda menunjukkan hasil yang lebih akurat daripada metode moving average.

Penelitian pada bursa efek berbagai negara juga tidak berhasil membuktikan keunggulan metode moving average dalam memprediksi arah perubahan atau pergerakan harga saham. Penggunaan metode moving average justru menghasilkan laba yang negatif karena prediksinya yang kurang akurat (Milionis \& Papanagiotou, 2013; Pavlov \& Hurn, 2012). 
Berbagai hasil penelitian yang beragam mengenai keakuratan metode moving average mengindikasikan bahwa keefektifan metode moving average tidak dapat diyakini akan berlaku pada berbagai konteks bursa efek yang berbeda dan periode amatan yang berbeda. Penelitian ini memberikan bukti empiris bahwa dalam konteks Bursa Efek Indonesia, khususnya saham-saham LQ45 yang diamati dalam jangka pendek, metode moving average terbukti secara statistik signifikan akurat dalam memprediksi arah perubahan atau pergerakan harga saham.

\section{SIMPULAN}

Penelitian ini memberikan bukti empiris keakuratan metode moving average dalam memprediksi arah pergerakan harga saham. Pengujian dengan MannWhitney menunjukkan tidak adanya perbedaan antara prediksi pergerakan harga saham dan kenyataannya.

Penelitian ini memiliki implikasi bagi para investor di Bursa Efek Indonesia. Para investor dapat mempertimbangkan untuk mempergunakan metode moving average untuk membantu memprediksi arah pergerakan harga saham, khususnya saham LQ45 dalam jangka pendek. Dengan kemampuan prediksi yang lebih akurat maka diharapkan akan dapat dihasilkan keputusan investasi yang tepat pula untuk memaksimalkan keuntungan investasi di bursa efek. Analisis teknikal dengan metode moving average ini juga dapat membantu investor meminimalisir risiko investasi dengan mengurangi kemungkinan kesalahan dalam pengambilan keputusan investasi.

Penelitian ini juga mengindikasikan bahwa keakuratan metode moving average belum dapat digeneralisasi pada berbagai konteks bursa efek yang berbeda dan periode amatan yang berbeda. Dengan demikian, disarankan pula kepada investor untuk juga mempertimbangkan penggunaan metode analisis teknikal lain seperti stochastic, relative strength index, bollinger band, dan sebagainya, bersamaan dengan metode moving average. Penggunaan berbagai metode analisis teknikal diharapkan dapat memberikan petunjuk yang lebih optimal dalam pengambilan keputusan investasi yang lebih tepat.

Mengingat penelitian ini hanya membatasi diri pada pengamatan sahamsaham LQ45 dalam jangka pendek, penelitian berikutnya diharapkan dapat melakukan pengujian pada saham-saham indeks yang berbeda dengan periode amatan yang pendek atau tetap menggunakan saham-saham LQ45 namun dengan periode amatan yang lebih panjang. Hal ini penting dilakukan untuk dapat membuktikan lebih jauh apakah dalam konteks bursa efek Indonesia keakuratan dan keunggulan metode moving average dapat digeneralisasi pada konteks berbagai indeks saham berbeda dan berbagai jangka waktu amatan berbeda.

\section{REFERENSI}

Ahmed, M. I., Ghohui, W., Hasan, M., Sattar, A., Ahmed, M., \& Rehman, R. U. (2018). Performance of Moving Average Investment Timing Strategy in UK Stock Market: Individual Stocks versus Portfolios. Journal of Economic and 
Social Studies, 7(2), 5-21. https://doi.org/10.14706/jecoss 17722

Ardani, N., Murhadi, W. R., \& Marciano, D. (2011). Investasi: Komparasi Strategi Buy and Hold dengan Pendekatan Teknikal. Jurnal Akuntansi Dan Keuangan, 14(1). https://doi.org/10.9744/jak.14.1.32-44

Burns, S., \& Burns, H. (2015). Moving Averages 101 : A Companion Guide. Stolly Media, LLC.

de Souza, M. J. S., Ramos, D. G. F., Pena, M. G., Sobreiro, V. A., \& Kimura, H. (2018). Examination of the profitability of technical analysis based on moving average strategies in BRICS. Financial Innovation. https://doi.org/10.1186/s40854-018-0087-z

Eduardus Tandelilin. (2010). Portofolio dan Investasi.

Glabadanidis, P. (2015). Market Timing With Moving Averages. International Review of Finance. https://doi.org/10.1111/irfi.12052

Halim, A. (2015). Analisis Investasi dan Aplikasinya. Jakarta. Salemba Empat. Jakarta: Salemba Empat.

Han, Y., Yang, K., \& Zhou, G. (2013). A new anomaly: The cross-sectional profitability of technical analysis. Journal of Financial and Quantitative Analysis. https://doi.org/10.1017/S0022109013000586

hartono, D. (2018). Analisis Saham Dengan Metode Guppy Multiple Moving Average Study Kasus : Pergerakan Saham Unilever Periode Januari Desember 2017. Jurnal Ekonomi, volume 20, 300-315.

Kahn, M. N. (2010). Technical Analysis Plain and Simple, Third Edition Charting the Markets in Your Language.

Ko, K. C., Lin, S. J., Su, H. J., \& Chang, H. H. (2014). Value investing and technical analysis in Taiwan stock market. Pacific Basin Finance Journal. https://doi.org/10.1016/j.pacfin.2013.10.004

Kresta, A., \& Franek, J. (2015). Analysis of Moving Average Rules Applicability in Czech Stock Market. Procedia Economics and Finance, 30, 364-371. https://doi.org/10.1016/S2212-5671(15)01303-9

Lukas Setia Atmaja. (2011). WhoWants To Be A Smiling Investor: cara termudah belajar investasi saham. gramedia.

Mahalanie, G. (2016). Pengaruh Analisis Teknikal Simple Moving Average, Relative Strength Index, Moving Average Convergence Divergence Dan 
Volume Perdagangan Saham Masa Lalu Terhadap Harga Saham Bursa Efek Indonesia (Universitas Sumatra Utara). Retrieved from http://repository.usu.ac.id/handle/123456789/65398

Marshall, B. R., Nguyen, N. H., \& Visaltanachoti, N. (2017). Time series momentum and moving average trading rules. Quantitative Finance. https://doi.org/10.1080/14697688.2016.1205209

May, E. (2011). Smart Traders Not Gamb - Ellen May .pdf(11th ed.). Jakarta: PT. Gramedia Pustaka Utama.

Mellya Embun Baining, M. S. F. (2017). Analisis Teknik Penggunaan Moving Average, Relative Strangth Index dan Bollinger Bands Dalam Menghasilkan Return Ssaham Pada Perusahaan Yang Terdaftar di Jakarta Islamic Index (JII). J urnal Syari'ah, Vol.V(no.2).

Milionis, A. E., \& Papanagiotou, E. (2013). Decomposing the predictive performance of the moving average trading rule of technical analysis: The contribution of linear and non-linear dependencies in stock returns. Journal of Applied Statistics. https://doi.org/10.1080/02664763.2013.818624

Mumpuni, melvin; harris D. (2017). Panduan Berinvestasi Saham Untuk Pemula. PT.Solusi Finansialku Indonesia.

Nugraheni, lucy ratna. (2019). Profitabilitas Analisis Teknikal Saham Menggunakan Simple Moving Average, Dual Moving Average, dan Trading Range Breakout Pada Saham LQ45 dan Non-LQ45 yang Terdaftar di Bursa Efek Indonesia. Retrieved from http://etd.repository.ugm.ac.id

Ong, E. (2016). Technical Analysis for Mega Profit (revisi). PT. Gramedia Pustaka Utama.

Parama Asthri, D. dwi. (2016). analisis teknikal dengan indikator moving average convergence divergence untuk menentukan sinyal membeli dan menjual dalam perdagangan saham (studi pada perusahaan sub sektor makanan dan minuman di BEI tahun 2013-2015. Jurnal Administrasi Bisnis (JAB), 33 no.2.

Pavlov, V., \& Hurn, S. (2012). Testing the profitability of moving-average rules as a portfolio selection strategy. Pacific Basin Finance Journal. https://doi.org/10.1016/j.pacfin.2012.04.003

Prasetyo, P., Laely, N., \& Subagyo, H. (2019). Analisis Komparatif Penggunaan Metode Stochastic, Moving Average Dan MACD Dalam Mendapatkan Keuntungan Optimal Dan Syar'i (Study Pada Jakarta Islamic Index 2016 2018). JIMEK : Jurnal Ilmiah Mahasiswa Ekonomi. 
https://doi.org/10.30737/jimek.v2i1.414

Putri, A. P., \& Mesrawati, M. (2020). Pengaruh Analisis Teknikal Terhadap Trend Pergerakan Harga Saham Perusahaan Subsektor Hotel Dan Restoran.

Ekuitas (Jurnal Ekonomi Dan Keuangan), 3(3), 324.

https://doi.org/10.24034/j25485024.y2019.v3.i3.4161

Raudys, A., \& Pabarškaitè, Ž. (2018). Optimising the smoothness and accuracy of moving average for stock price data. Technological and Economic

Development of Economy, 24(3), 984-1003. https://doi.org/10.3846/20294913.2016.1216906

Schlotmann, R., \& Czubatinski, M. (2019). Trading : Technical Analysis Master Class.

Shellina Dessy. (2008). Evaluasi Simple Moving Average Dan Relative Strength Index. (2008).

Toms, M. C. (2011). The Technical Analysis Method of Moving Average Trading: Rules That Reduce the Number of Losing Trades. (August), 185.

Widoatmodjo, S. (2015). Pengetahuan Pasar Modal untuk Konteks Indonesia (edisi pert). elex media komputindo.

Widodo, D., \& Hansun, S. (2016). Implementasi Simple Moving Average dan Exponential Moving Average dalam Menentukan Tren Harga Saham Perusahaan. Jurnal ULTIMATICS, 7(2), 113-124.

https://doi.org/10.31937/ti.v7i2.354

www.idx.co.id. (n.d.). PT Bursa Efek Indonesia. Retrieved April 11, 2020, from https://www.idx.co.id/produk/indeks/

www.idx.co.id. (2019). saham. Retrieved from https://idx.co.id/produk/saham/ website: https://idx.co.id/produk/saham/

Zakamulin, V. (2015). Market Timing with a Robust Moving Average. SSRN Electronic Journal. https://doi.org/10.2139/ssrn.2612307

Zakamulin, V. (2017). Market Timing With Moving Average.

Zhu, H., Jiang, Z. Q., Li, S. P., \& Zhou, W. X. (2015). Profitability of simple technical trading rules of Chinese stock exchange indexes. Physica A: Statistical Mechanics and Its Applications. https://doi.org/10.1016/j.physa.2015.07.032 